\title{
Diet of four annual killifishes: an intra and interspecific comparison
}

\author{
Gabriel Laufer ${ }^{1}$, Matías Arim ${ }^{1,2}$, Marcelo Loureiro, ${ }^{1,3}$, Juan Manuel Piñeiro-Guerra ${ }^{1}$, \\ Sabrina Clavijo-Baquet ${ }^{2}$ and César Fagúndez ${ }^{4}$
}

We examined the diet of 4 annual fishes, Austrolebias viarius, Austrolebias cheradophilus, Austrolebias luteoflammulatus and Cynopoecilus melanotaenia inhabiting temporal ponds of southeastern Uruguay, by analysis of stomach contents. Fishes were captured from fifty ephemeral ponds of Castillos Lagoon basin, in the region of the Humedales del Este. We identified 13099 individual prey items extracted from 669 stomachs of the four captured species. In the studied system, annual killifishes represents the most abundant and conspicuous top predators. Killifishes are generalist key predators at the ephemeral ponds of the studied system, consuming mostly aquatic items. Zooplancton represented the bulk of the diet in the four analyzed species, followed by eggs, algae and diatoms. Insects are the next group in prey number, as follows: Diptera larvae (especially Chironomidae and Cullicidae), Ephemeroptera (especially Betidae), and coleopteran larvae (especially Dytiscidae). Acari are also important prey in number. The four fish species differ in diet composition and in diet richness. A general pattern of differences in diet richness among killifish species and demographic groups could be related to variations in body sizes. As top predators annual killifishes are an important component of the temporal pond ecosystems. Understanding the natural history of this species and their communities is necessary in order to conserve them.

Nós examinamos a dieta de 4 peixes anuais, Austrolebias viarius, Austrolebias cheradophilus, Austrolebias luteoflammulatus e Cynopoecilus melanotaenia, que habitam poças temporárias do sudeste do Uruguai, através da análise de conteúdo estomacal. Os peixes foram capturados em cinco poças temporárias da bacia da lagoa Castillos, na região de Humedales del Este. Nós identificamos 13099 itens de presas estraídos de 669 estômagos das quatro espécies. No sistema estudado, peixes anuais representam os predadores de topo mais abundantes e conspícuos. Os rivulídeos são predadores generalistas nas poças temporaries estudadas, consumindo principalmente itens aquáticos. Zooplâncton representou o item principal da dieta para as quatro espécies, seguido de ovos, algas e diatomáceas. Insetos compoem o próximo grupo em número de presas, como segue: larvas de Diptera (especialmente Chironomidae e Cullicidae), Ephemeroptera (especialmente Betidae), e larvas de Coleoptera (especialmente Dytiscidae). Ácaros foram também presas importantes em número. As quatro espécies de peixes diferem na composição e riqueza das dietas. O padrão geral de diferenciação da dieta entre espécies e grupos demográficos de rivulídeos pode ser relacionado à variação do tamanho corporal. Como predadores de topo, os rivulídeos anuais são um componente importante dos ecossistemas de poças temporárias. A compreensão da história natural destas espécies e de suas comunidades é necessária a sua conservação.

Key words: Annual fishes, Foraging behavior, Predators, Food analysis.

\footnotetext{
${ }^{1}$ Sección Zoología Vertebrados, ${ }^{4}$ Sección Ecología, Facultad de Ciencias, Universidad de la República, Uruguay, Iguá 4225 Piso 9 Sur, Montevideo, Uruguay.

${ }^{2}$ Center for Advanced Studies in Ecology \& Biodiversity (CASEB) and Departamento de Ecología, Facultad de Ciencias Biológicas, Pontificia Universidad Católica de Chile, Santiago, CP 6513677, Chile.

${ }^{3}$ Departamento de Ictiología, Museo Nacional de Historia Natural y Antropología, Juan Carlos Gómez 582, Montevideo, Uruguay.
} 


\section{Introduction}

Diet is a basic determinant of organism biology, being related with most of the ecological attributes (Hughes, 1993). Diet has been associated with morphology (Winemiller, 1991), physiology (McNab, 2002), behaviour (Ward et al., 2004), population abundances (Brown et al., 2004) and dynamics (Berryman, 1999), community structure (Arim et al., 2007) and even ecosystem processes (Thébault \& Loreau, 2006). As a consequence, knowing species trophic behavior represents a central step in order to advance in understanding its natural history.

Living in time-constrained habitats, such as ephemeral ponds with periodic drying, imposes several constrains to species behaviour, development, and life history (Ludwig \& Rowe, 1990). Biological and environmental factors interact to determine the structure of the temporary pond communities (Wilbur, 1987). Mortality risk can be high in these habitats due to desiccation and predation by odonates, beetles and hemipterans (Wilbur, 1987). Animals found in that habitatsmostly macroinvertebrate and amphibian larvae-show adaptations to deal with that particular hydrological regime, such as rapid colonization and growth rate, high phenotypic plasticity (Wilbur, 1987; Marcus \& Weeks, 1997; Relyea \& Werner, 2000; Mura et al., 2003) or the presence of a resistance phase in their life cycle (e.g. diapause). Periodic drying excludes species unable to cope with that physical stress, preventing the colonization of key predators such as fishes and some invertebrate (Skelly, 1995). In fact, many amphibians with no anti-fish predator defenses are restricted to ephemeral pools (Kats et al., 1988; Peltzer \& Lajmanovich, 2004). However, the annual killifishes (Cyprinodontiformes, Aplocheiloidei) are fish species that evolved in that particular habitat, having a resistance phase in their life cycle (Wourms, 1972).
Annual killifishes originated independently in Africa and South America and have evolved to tolerate the desiccation constrains by completion of their entire cycle within less than one year (Costa, 1995a; Nelson, 2006). This adaptation requires notable high growing and development rates (Errea $\&$ Danulat, 2001). When ponds dry out, adults die and their eggs remain in diapause buried in the substrate, hatching on the next year, with the return of favorable conditions (Wourms, 1972; Arezzo et al., 2005). While tadpoles have the possibility of regulating their metamorphosis time (exit of the temporary pond) based on the environmental conditions, for annual fishes the only option is the fast growth and maturation because its whole cycle passes in ephemeral ponds. This fishes require lying eggs before the pond dries (Scheel, 1962), so energetic budgets imply growing and reproduction requirements, probably with a great ingestion necessity.

Despite the uniqueness of this life cycle, there is little information about their life history and diet (Costa, 1995a; Arenzon et al., 2001). The ecological and evolutionary contexts of temporal ponds have profound implications in species biology, well studied in amphibians and invertebrates, but not in fishes. The objective of this study was to describe and analyze the diet of four killifish species that coexist in a temporary pond system, in southeastern Uruguay: Cynopoecilus melanotaenia (Regan, 1912), Austrolebias luteoflammulatus (Vaz-Ferreira, Sierra de Soriano \& Scaglia de Paulete, 1964), A. viarius (Vaz-Ferreira, Sierra de Soriano \& Scaglia de Paulete, 1964) and A. cheradophilus (Vaz-Ferreira, Sierra de Soriano \& Scaglia de Paulete, 1964).

\section{Material and Methods}

Study Area. The present study is based on diet analysis of individuals collected in a costal lagoon basin which outflows into the Atlantic ocean, southeastern Uruguay, in the region
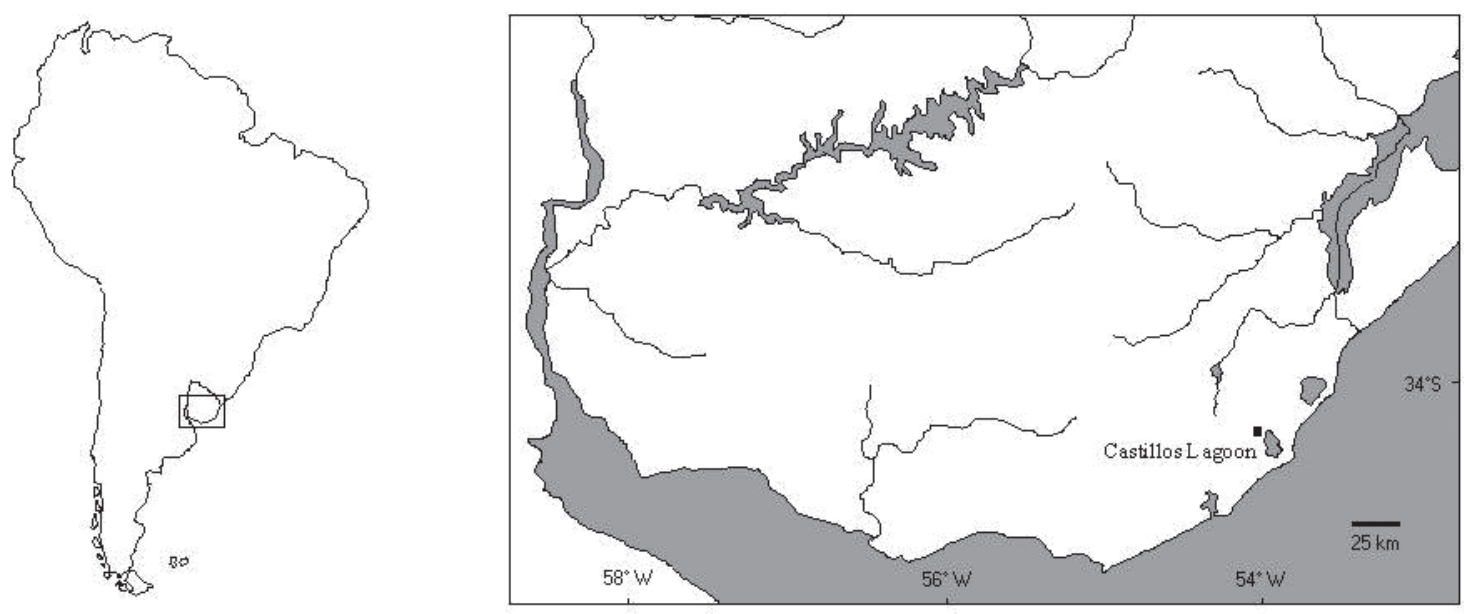

Fig. 1. Map of the study site area. The sampled temporary pools are located in the Castillos Lagoon Basin, about $60 \mathrm{~km}$ from Brazilian border. 
of the Humedales del Este (Eastern Wetlands), Rocha; declared Biosphere Reserve by UNESCO, program MAB (Fig. 1). A system of 50 temporal ponds was studied, located in grasslands (private farms used for cattle). Ponds consist of ground depressions with a depth that does not surpass 30 $\mathrm{cm}$ and a very variable area (from 1 to $25000 \mathrm{~m}^{2}$ ). During autumn and winter, these pools are usually water plenty, time at which the pluvial water contributions surpass the losses by evaporation; quickly dried in the beginning of higher spring temperatures. Ponds display an important diversity of organisms, macrophytes and invertebrates as well with different adaptations to this particular hydrological regime. Present vertebrates are fishes and anurans (larvae and adults).

Fish sampling and diet analysis. Fishes were collected in winter of 2006 with hand-net $(15 \times 20 \mathrm{~cm}, 1 \mathrm{~mm}$ mesh). Fishes were captured and euthanized with a lethal dose of 2phenoxyethanol and immediately fixed in formaldehyde solution (4\%). At laboratory, specimens were identified at the species level, measured with a digital caliper (to the nearest of $0.01 \mathrm{~mm}$ ) for standard length (STL), and classified in demographic groups according to the presence of visible sexual characters (coloration pattern and fin configuration; Costa, 2006) as follows: juveniles (J), females (F), males (M) or not identified (Ni). The data from those individuals that could not be identified were used for species level analysis, but not for demographic comparisons. All specimens analyzed were placed in the Fish Collection of Facultad de Ciencias, Montevideo (Institutional Code: ZVC-P).

Preserved specimens were dissected and all food contained in their stomach was removed and spread on a glass slide for identification under stereomicroscope. References on aquatic invertebrates and zooplankton were consulted for prey identification (Burgis \& Morris, 1987; Consoli \& Olivera, 1994; Peña, 2001; Thorp \& Covich, 2001; Motta \& Uieda, 2004; Costa et al., 2006).

Statistical Analysis. For each species the number of individuals, mean length, number of prey and prey richness were analyzed, discriminating among males, females and juvenile individuals. Differences between frequency variables (fish individuals, prey number and prey richness) were evaluated by G-test at two different levels (Sokal \& Rohlf, 1995). First, data were compared between M, F and J of each species. If significant differences were detected, a G-test was realized for each pair of demographic groups (M-F, M-J, F-J). In all G-tests the null hypothesis was an equal distribution among demographic groups (Sokal \& Rohlf, 1995). The significance of standard length difference between demographic groups was evaluated by a one-way ANOVA, using Fisher LSD post hoc analysis to evaluate differences between pair of species (Sokal \& Rohlf, 1995). STL of $A$. viarius was transformed $\left(\mathrm{STL}^{\prime}=\sin ^{-1} \mathrm{STL}\right)$ in order to obtain the necessary test assumptions.

Diversity patterns are strongly affected by the number of observations used in its estimation (Gotelli \& Graves, 1996).
Rarefaction is a robust method to describe and contrast diversity patterns when different sample sizes are involved (Arim \& Barbosa, 2002). Further, rarefaction is the only diversity measure that is sensitive to rare species and is unbiased by sample size (Magurran, 1988). In the analysis of temporal or interspecific diet patterns, the use of rarefaction represents a robust approach (Arim \& Jaksic, 2005) that brings a better insight about diet patterns than diversity indices (Naya et al., 2002). Rarefaction involves the estimation of the expected richness for a series of subsamples from the prey abundance distribution (Gotelli \& Graves, 1996). For each species rarefaction diversity curves were estimated for the three demographic groups (M, F, and J). Subsamples where constructed with individual fishes (Gotelli \& Colwell, 2001) rather than with individual preys (e.g. Naya et al., 2002). For each rarefaction curve, sub-samples from one fish to the effectively observed fish number were taken and species richness retained. This procedure was repeated 10000 times estimating the median richness and confidence interval at $95 \%$ with percentiles $0.025,0.5$ and 0.975 (Manly, 1997). This re-sampling method eliminates the assumption of underling distributions in rarefaction estimation (e.g. Rosenzweig, 1999). Rarefaction curves where used to contrast diet diversity within species - among demographic groups-and among species - considering species diet as a whole.

Differences in standard length (STL) between species were studied with ANOVA analysis. In order to get normality STL was $\log 10$-transformed. A Fisher LSD test was performed to look for differences between species pairs (Sokal \& Rohlf, 1995).

For the analysis of differences in diet composition between species, consumed items were categorized in seven classes: Basal items, Primary Consumers (PC: Zooplankton, Molluscs and Other), Predators (P: Adult and Larva), and Non Aquatic items. Differences among species were evaluated by G-test for each item class (Sokal \& Rohlf, 1995) and association of killifishes species with diet item categories was analyzed by a Canonical Correspondence Analysis (CCA), using frequencies (Greenacre, 1984). Diet richness composition was contrasted with a rarefaction procedure (Gotelli \& Graves, 1996).

\section{Results}

We identified 13099 individual prey items extracted from stomachs of the 669 collected individuals of the four fish species. Zooplancton represented the bulk of their diet, followed by eggs, algae and diatoms (Table 1). Insects were the next group in prey number, as follows: Diptera larvae (especially Chironomidae and Culicidae), Ephemeroptera (mostly represented by Baetidae larvae), and coleopteran larvae (especially Dytiscidae). Acari (Hydracarina) were also important prey in number. Other preys such as mollusks and Malacostraca also appear in relative important quantities in the gut content. Non aquatic preys were represented by adult dipterans, Collembolla and Aranea, in relatively low frequencies. 
Table 1. Diet of $A$. viarius $(A v)$, A. luteoflamulatus $(A l)$, A. cheradophilus $(A c)$ and $C$. melanotaenia $(C m)$ from temporary pools at Castillos lagoon basin, southeastern Uruguay. Gut content is presented for females (F), males (M), juveniles (J) and not identified individuals $(\mathrm{Ni})$. The first line $(\mathrm{N})$ details the number of analyzed fishes for each species and demographic group.

\begin{tabular}{|c|c|c|c|c|c|c|c|c|c|c|c|c|c|c|c|}
\hline & \multicolumn{4}{|c|}{$A v$} & \multicolumn{4}{|c|}{ Al } & \multicolumn{3}{|c|}{$A C$} & \multicolumn{4}{|c|}{$\mathrm{Cm}$} \\
\hline & $\mathrm{F}$ & $\mathrm{J}$ & $\overline{\mathrm{M}}$ & $\mathrm{Ni}$ & $\bar{F}$ & J J & $\bar{M}$ & $\mathrm{Ni}$ & $\bar{F}$ & $\bar{J} \mathrm{~J}$ & $\overline{\mathrm{M}}$ & $\bar{F}$ & J J & $\bar{M}$ & $\mathrm{Ni}$ \\
\hline $\mathrm{N}$ & 234 & 113 & 76 & 63 & 25 & 24 & 59 & 3 & 16 & 4 & 18 & 9 & 9 & 2 & 14 \\
\hline Algae & 203 & 109 & 47 & 33 & 7 & 5 & 34 & 0 & 3 & 0 & 0 & 2 & 0 & 8 & 0 \\
\hline Diatom & 248 & 33 & 8 & 1 & 1 & 0 & 7 & 0 & 0 & 0 & 0 & 0 & 0 & 1 & 0 \\
\hline Seed & 1 & 3 & 3 & 0 & 0 & 0 & 0 & 0 & 0 & 0 & 0 & 0 & 0 & 0 & 0 \\
\hline Nematoda & 12 & 10 & 6 & 1 & 3 & 0 & 4 & 0 & 0 & 0 & 0 & 0 & 0 & 1 & 0 \\
\hline Ostracoda & 283 & 144 & 128 & 77 & 94 & 48 & 175 & 2 & 2 & 2 & 23 & 12 & 1 & 45 & 2 \\
\hline Cladocera & 2643 & 1167 & 723 & 719 & 82 & 121 & 264 & 20 & 61 & 10 & 30 & 32 & 14 & 56 & 58 \\
\hline Copepoda & 37 & 26 & 15 & 3 & 4 & 2 & 5 & 4 & 3 & 0 & 0 & 0 & 0 & 0 & 0 \\
\hline Cyclopoida & 195 & 8 & 64 & 4 & 1 & 3 & 36 & 0 & 0 & 0 & 1 & 29 & 0 & 38 & 1 \\
\hline Calanoida & 990 & 399 & 427 & 376 & 309 & 129 & 277 & 10 & 55 & 6 & 22 & 26 & 2 & 85 & 34 \\
\hline Bivalvia & 2 & 0 & 0 & 3 & 0 & 0 & 0 & 0 & 1 & 0 & 5 & 0 & 0 & 0 & 0 \\
\hline Ancylidae & 4 & 0 & 0 & 0 & 0 & 0 & 0 & 0 & 0 & 0 & 0 & 0 & 0 & 0 & 0 \\
\hline Planorbidae & 22 & 0 & 2 & 1 & 0 & 0 & 1 & 0 & 3 & 0 & 6 & 2 & 0 & 0 & 0 \\
\hline Ampullaridae & 5 & 0 & 6 & 0 & 0 & 0 & 3 & 0 & 1 & 0 & 0 & 1 & 0 & 0 & 0 \\
\hline Operculum & 5 & 3 & 3 & 1 & 0 & 0 & 0 & 0 & 0 & 1 & 1 & 0 & 0 & 0 & 2 \\
\hline Oligochaeta & 1 & 0 & 0 & 0 & 3 & 0 & 0 & 0 & 1 & 0 & 1 & 0 & 0 & 0 & 0 \\
\hline Arthropoda & 18 & 2 & 5 & 2 & 1 & 0 & 2 & 1 & 0 & 0 & 2 & 0 & 0 & 0 & 0 \\
\hline Amphipoda & 9 & 3 & 4 & 3 & 2 & 1 & 10 & 0 & 0 & 1 & 3 & 0 & 0 & 0 & 0 \\
\hline Parastacus & 2 & 0 & 0 & 0 & 0 & 0 & 0 & 0 & 1 & 0 & 1 & 0 & 0 & 0 & 0 \\
\hline Aranea & 0 & 0 & 0 & 1 & 0 & 0 & 0 & 0 & 0 & 0 & 1 & 0 & 0 & 0 & 0 \\
\hline Hydracarina & 66 & 16 & 17 & 10 & 11 & 4 & 12 & 0 & 0 & 1 & 3 & 1 & 0 & 3 & 0 \\
\hline Insecta & 10 & 5 & 5 & 3 & 1 & 0 & 1 & 0 & 0 & 0 & 1 & 0 & 0 & 0 & 0 \\
\hline Dytiscidae (larva) & 16 & 7 & 9 & 8 & 6 & 4 & 9 & 0 & 0 & 1 & 5 & 0 & 0 & 5 & 0 \\
\hline Haliplidae (larva) & 0 & 0 & 1 & 0 & 0 & 0 & 0 & 0 & 0 & 0 & 0 & 0 & 0 & 0 & 0 \\
\hline $\begin{array}{l}\text { Chrysom elidae } \\
\text { (larva) }\end{array}$ & 0 & 0 & 2 & 0 & 0 & 0 & 0 & 0 & 0 & 0 & 0 & 0 & 0 & 0 & 0 \\
\hline $\begin{array}{l}\text { Hydrophilidae } \\
\text { (larva) }\end{array}$ & 3 & 4 & 2 & 3 & 0 & 0 & 1 & 0 & 1 & 0 & 1 & 0 & 0 & 1 & 0 \\
\hline $\begin{array}{l}\text { Ephem eroptera } \\
\text { (larva) }\end{array}$ & 0 & 2 & 0 & 0 & 0 & 0 & 0 & 0 & 0 & 0 & 0 & 0 & 0 & 0 & 0 \\
\hline Baetidae (larva) & 34 & 9 & 28 & 18 & 3 & 6 & 8 & 0 & 12 & 0 & 14 & 2 & 0 & 2 & 0 \\
\hline Diptera & 0 & 0 & 0 & 0 & 0 & 0 & 0 & 0 & 0 & 0 & 1 & 0 & 0 & 0 & 0 \\
\hline Tachinidae & 1 & 0 & 0 & 0 & 0 & 0 & 0 & 0 & 0 & 0 & 0 & 0 & 0 & 0 & 0 \\
\hline $\begin{array}{l}\text { Chironomidae } \\
\text { (larva) }\end{array}$ & 113 & 2 & 13 & 4 & 3 & 1 & 18 & 0 & 1 & 0 & 1 & 5 & 0 & 11 & 0 \\
\hline Tipulidae (larva) & 0 & 0 & 0 & 0 & 0 & 0 & 0 & 0 & 1 & 0 & 0 & 0 & 0 & 1 & 0 \\
\hline Culicidae (larva) & 17 & 1 & 8 & 3 & 0 & 7 & 32 & 0 & 5 & 1 & 2 & 2 & 0 & 0 & 1 \\
\hline Culicidae (pupa) & 3 & 0 & 0 & 1 & 0 & 0 & 1 & 0 & 0 & 0 & 0 & 0 & 0 & 1 & 0 \\
\hline Culicidae & 11 & 0 & 0 & 0 & 0 & 0 & 13 & 0 & 0 & 0 & 0 & 0 & 0 & 0 & 0 \\
\hline $\begin{array}{l}\text { Ceratopogonidae } \\
\text { (larva) }\end{array}$ & 12 & 11 & 4 & 11 & 2 & 2 & 9 & 0 & 1 & 0 & 3 & 2 & 0 & 2 & 1 \\
\hline Tabanidae (larva) & 25 & 5 & 9 & 1 & 0 & 0 & 9 & 0 & 2 & 0 & 1 & 2 & 0 & 2 & 0 \\
\hline Corixidae & 0 & 0 & 2 & 1 & 0 & 0 & 1 & 0 & 0 & 0 & 1 & 0 & 0 & 0 & 0 \\
\hline Notonectidae & 0 & 0 & 1 & 0 & 0 & 0 & 0 & 0 & 0 & 0 & 0 & 0 & 0 & 0 & 0 \\
\hline Hym enoptera & 0 & 0 & 1 & 1 & 0 & 0 & 0 & 0 & 0 & 0 & 0 & 0 & 0 & 0 & 0 \\
\hline Odonata (larva) & 0 & 0 & 1 & 0 & 0 & 0 & 0 & 0 & 0 & 0 & 0 & 0 & 0 & 0 & 0 \\
\hline Zygoptera (larva) & 2 & 0 & 1 & 2 & 0 & 0 & 1 & 0 & 0 & 0 & 0 & 0 & 0 & 0 & 0 \\
\hline A nisoptera (larva) & 3 & 0 & 1 & 1 & 0 & 0 & 2 & 0 & 1 & 0 & 0 & 0 & 0 & 0 & 0 \\
\hline Aphidae & 1 & 0 & 1 & 2 & 0 & 0 & 1 & 0 & 0 & 0 & 0 & 0 & 0 & 0 & 0 \\
\hline Trichoptera (larva) & 4 & 1 & 2 & 1 & 0 & 1 & 0 & 0 & 0 & 0 & 4 & 0 & 0 & 0 & 0 \\
\hline Lepydoptera (larva) & 0 & 0 & 1 & 0 & 0 & 0 & 1 & 0 & 0 & 0 & 0 & 0 & 0 & 0 & 0 \\
\hline Psocoptera & 2 & 0 & 0 & 0 & 0 & 0 & 0 & 0 & 0 & 0 & 0 & 0 & 0 & 0 & 0 \\
\hline Collem bola & 88 & 0 & 1 & 0 & 0 & 0 & 1 & 1 & 0 & 0 & 0 & 0 & 0 & 0 & 0 \\
\hline Egg & 99 & 29 & 83 & 12 & 43 & 24 & 96 & 18 & 71 & 0 & 10 & 1 & 0 & 3 & 0 \\
\hline Egg mass & 3 & 0 & 0 & 0 & 0 & 0 & 0 & 0 & 0 & 0 & 0 & 0 & 0 & 0 & 0 \\
\hline $\begin{array}{l}\text { Cynopoecilus } \\
\text { melanotaenia }\end{array}$ & 0 & 0 & 0 & 0 & 0 & 0 & 0 & 0 & 1 & 0 & 0 & 0 & 0 & 0 & 0 \\
\hline Unidentified & 17 & 14 & 2 & 1 & 0 & 1 & 3 & 0 & 3 & 0 & 1 & 3 & 1 & 2 & 1 \\
\hline
\end{tabular}

Intraspecific analysis. Austrolebias viarius has been the dominant species in the system representing $71.21 \%$ of the total number of individuals collected. The proportion of individuals observed in demographic groups differed $\left(G_{2}=93.10\right.$, $p<0.05$, Fig. 2a), being $F$ most frequent than $J$ followed by M. Males were larger than $\mathrm{F}$, followed by $\mathrm{J}\left(\mathrm{F}_{2,420}=\right.$ 77.92 , p $<0.05$, Fig. 2b). Total number of prey were higher in $F$, followed by $\mathrm{J}$ an then $\mathrm{M}\left(\mathrm{G}_{2}=2441, \mathrm{p}<0.05\right.$, Fig. $\left.2 \mathrm{c}\right)$ and prey richness was equal for all stages $\left(G_{2}=3.575, p=0.17\right.$, Fig. $\left.2 d\right)$. The rarefaction curves shows differences between demographic groups (Fig. 2). Males show the richest diet, followed by $\mathrm{F}$, and then $\mathrm{J}$.

Austrolebias luteoflammulatus were $18.18 \%$ of the total sample. The proportion between $\mathrm{F}$ and $\mathrm{J}$ did not differ, but $\mathrm{M}$ were the most numerous demographic group $\left(\mathrm{G}_{2}=20.60\right.$, $\mathrm{p}<0.05$, Fig. 3a). Demographic groups differ at STL 


\section{A. viarius}
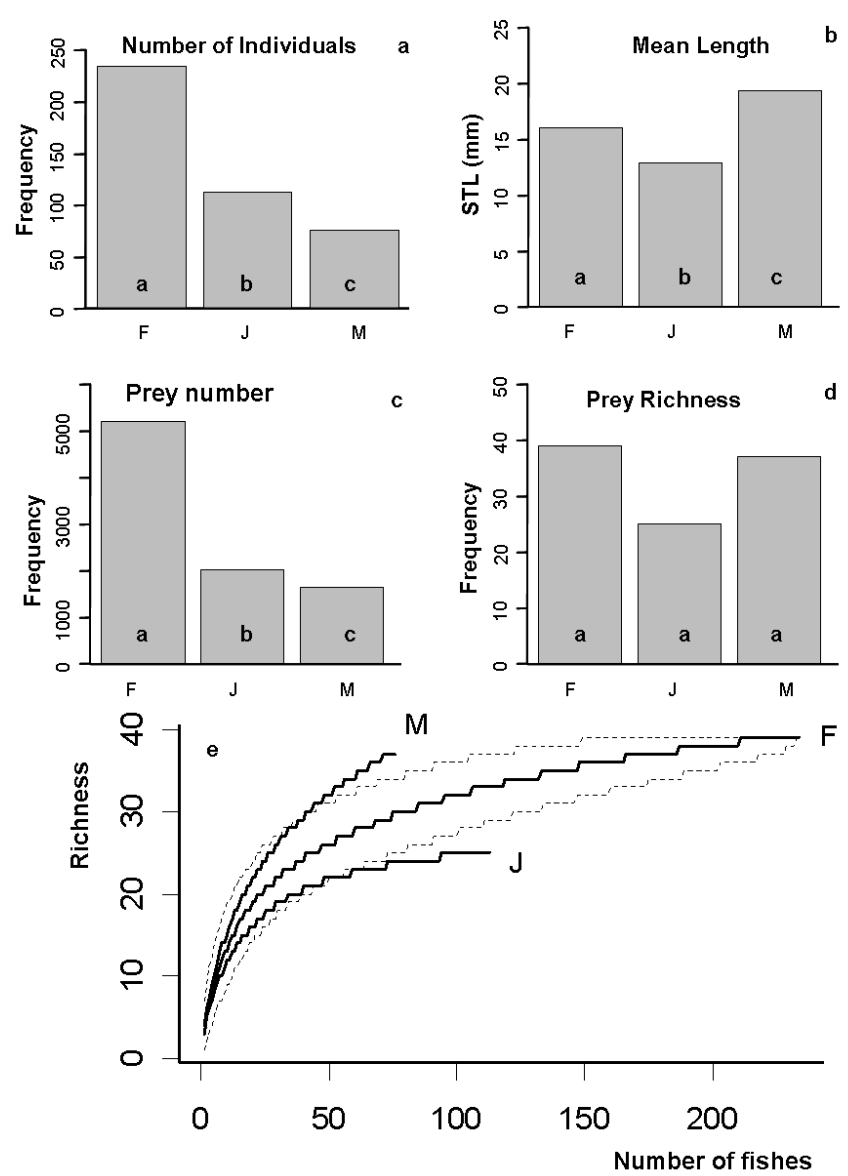

Fig. 2. Sampled fishes of $A$. viarius and differences between demographic groups (F, J and M) in: (a) number of collected individuals, (b) body sizes measured as STL, (c) total number of prey recorded at gut analysis, and (d) prey richness at the taxonomic level detailed in Table 1. (e) Rarefaction curves for each class. Dashed lines indicate the confident interval at $95 \%$.

$\left(\mathrm{F}_{2,105}=24.24, \mathrm{p}<0.05\right.$, Fig. 3b), being $\mathrm{M}$ the largest, followed by $\mathrm{F}$ and then J. Prey number was significantly higher at adult stages, specially at males $\left(\mathrm{G}_{2}=359.1, \mathrm{p}<0.05\right.$, Fig. $\left.3 \mathrm{c}\right)$. Differences in prey richness showed the same tendency but it was marginally significant $\left(\mathrm{G}_{2}=5.83, \mathrm{p}=0.0541\right.$, Fig. $\left.3 \mathrm{~d}\right)$. The rarefaction curves show differences between demographic groups, indicating a greater richness for $\mathrm{M}$ followed by $\mathrm{F}$ and J (Fig. 3).

Austrolebias cheradophilus were $4.21 \%$ of the total sample. $\mathrm{M}$ and $\mathrm{F}$ were the most frequent demographic groups $\left(\mathrm{G}_{2}=10.20, \mathrm{p}<0.05\right.$, Fig. $\left.4 \mathrm{a}\right)$. There was no significant difference between $\mathrm{M}$ and $\mathrm{F}$ number of individuals, and the same pattern is observed in body size $\left(\mathrm{F}_{2,22}=4.44, \mathrm{p}<0.05\right.$, Fig. $\left.4 \mathrm{~b}\right)$. Prey number was significantly higher at adult stages, especially at $\mathrm{F}\left(\mathrm{G}_{2}=198.1, \mathrm{p}<0.05\right.$, Fig. $\left.4 \mathrm{c}\right)$, but considering prey richness, $\mathrm{M}$ and $\mathrm{F}$ are equal and $\mathrm{J}$ have lower level $\left(\mathrm{G}_{2}=10.60, \mathrm{p}<0.05\right.$, Fig. 4d). The rarefaction analysis did not show significant

\section{A. Iuteoflammulatus}
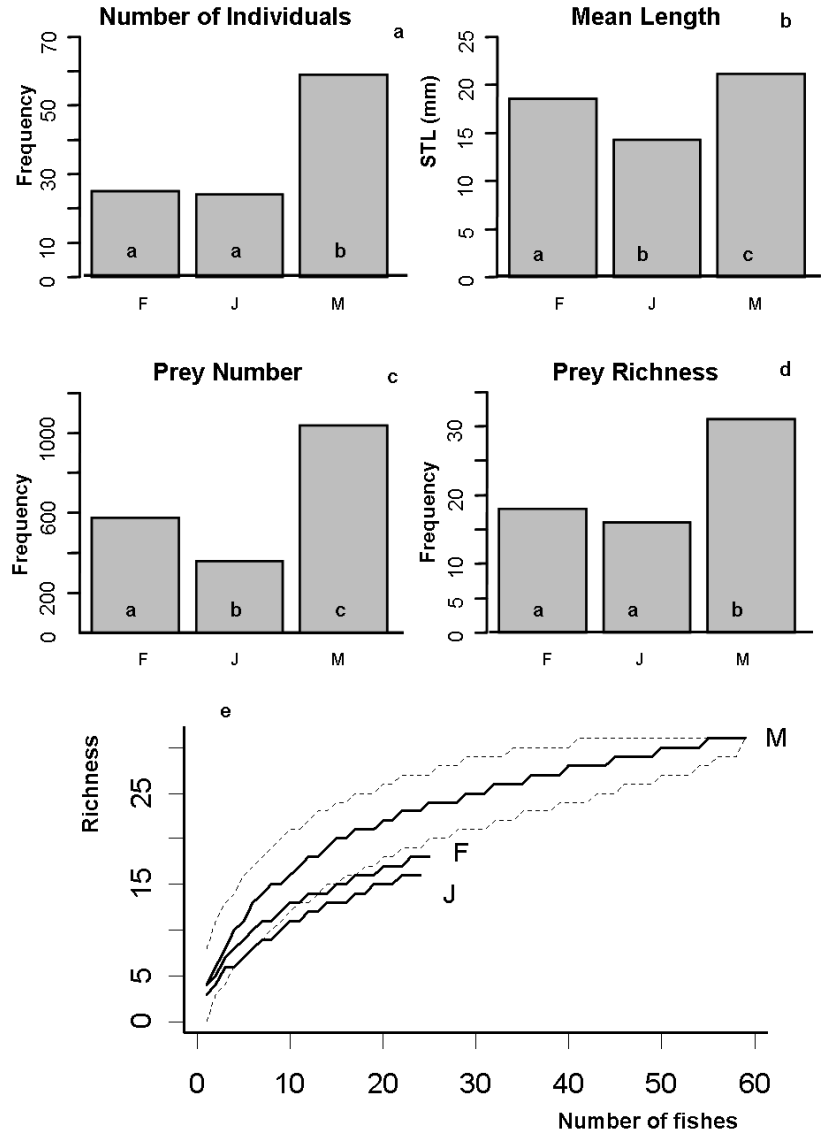

Fig. 3. Sampled fishes of A. luteoflammulatus and differences between demographic groups (F, J and $\mathrm{M}$ ) in: (a) number of collected individuals, (b) body sizes measured as STL, (c) total number of prey recorded at gut analysis, and (d) prey richness at the taxonomic level detailed in Table 1. (e) Rarefaction curves for each class. Dashed lines indicate the confident interval at $95 \%$.

differences for each demographic group, probably due to the small sample size (Fig. 4).

Cynopoecilus melanotaenia were $6.4 \%$ of the total sample. The proportion between demographic groups shows significant differences $\left(G_{2}=10.90, p<0.05\right.$, Fig. 5a) being the adults the predominant classes. In addition, proportions of $\mathrm{M}$ and $\mathrm{F}$ individuals did not differ. Males presented larger size than females $\left(\mathrm{F}_{2,35}=10.96, \mathrm{p}<0.05\right.$, Fig. $\left.5 \mathrm{~b}\right)$ and both presented larger sizes than juveniles. A significant large number of prey was observed for $\mathrm{M}$, followed by $\mathrm{F}$ and $\mathrm{J}$ $\left(\mathrm{G}_{2}=262.9, \mathrm{p}<0.05\right.$, Fig. $\left.5 \mathrm{c}\right)$. Considering prey richness, $M$ and $\mathrm{F}$ did not presented significant differences, while $\mathrm{J}$ presented and inferior richness $\left(G_{2}=10.47, p<0.05\right.$, Fig. $\left.5 d\right)$. The rarefaction analysis did not show significant differences for each demographic group, probably due to the small sample size (Fig. 5). 


\section{A. cheradophilus}
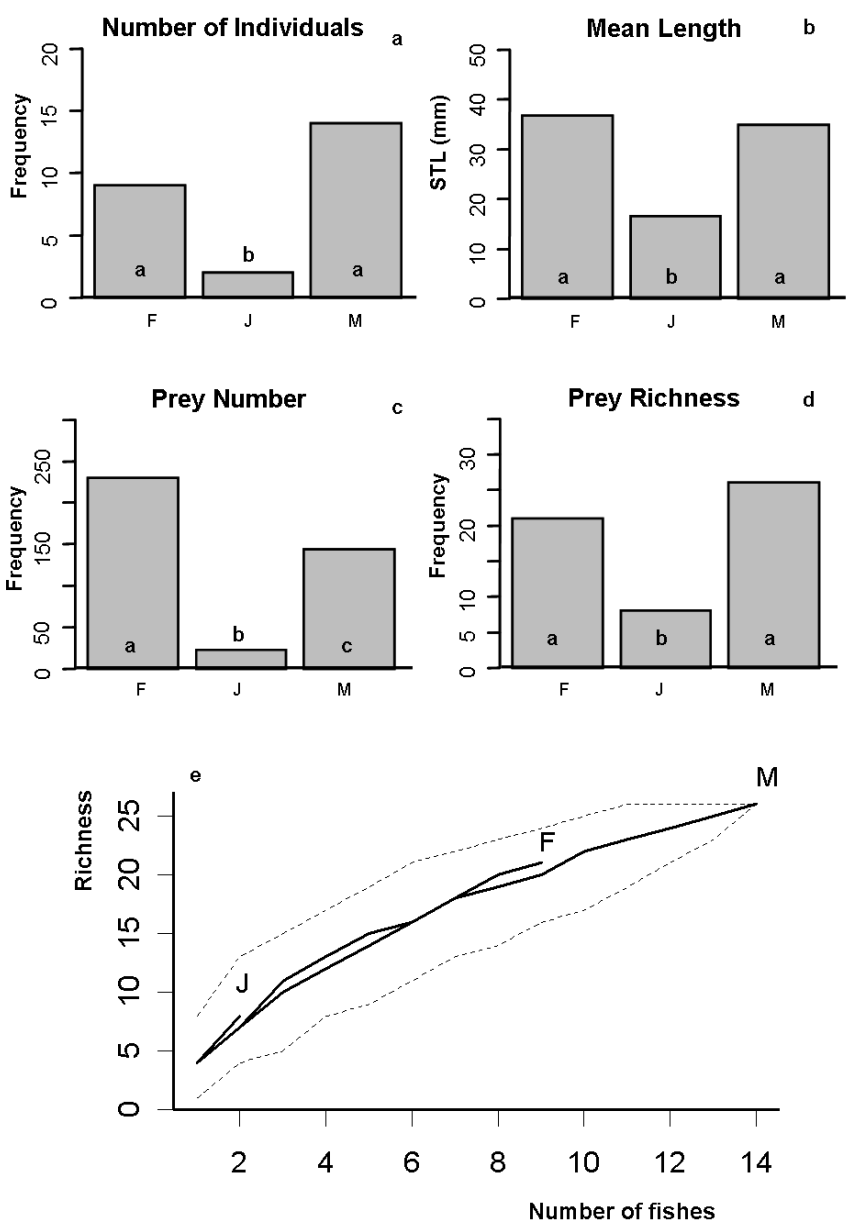

Fig. 4. Sampled fishes of $A$. cheradophilus and differences between demographic groups (F, J and M) in: (a) number of collected individuals, (b) body sizes measured as STL, (c) total number of prey recorded at gut analysis, and (d) prey richness at the taxonomic level detailed in Table 1. (e) Rarefaction curves for each class. Dashed lines indicate the confident interval at $95 \%$.

Interespecific analysis. The mean standard length STL differs among species $\left(\mathrm{F}_{3,590}=81.17, \mathrm{p}<0.001\right)$, being $A$. cheradophilus (mean STL $=34.00 \mathrm{~mm}$ ) the largest species followed by $A$. luteoflammulatus $($ mean STL $=18.99 \mathrm{~mm}$ ). This species is slightly larger than $A$. viarius (mean STL $=15.77 \mathrm{~mm}$ ) and $C$. melanotaenia $($ mean STL $=15.74 \mathrm{~mm})$, species that do show significant differences in body sizes at post hoc analysis. The four species rarefaction analysis show no differences between A. viarius and $A$. luteoflammulatus; $C$. melanotaenia displays lower, and A. cheradophilus higher prey richness (Fig. 6).

Prey group frequencies are different between species. The G-test for the each prey class shows significant differences between killifishes species (Table 2). The graphic resulted from the CCA, reveals differences in prey association with each fish species (Fig. 7). The first axis separates $A$. cheradophilus from the rest of the system species. This

\section{C. melanotaenia}
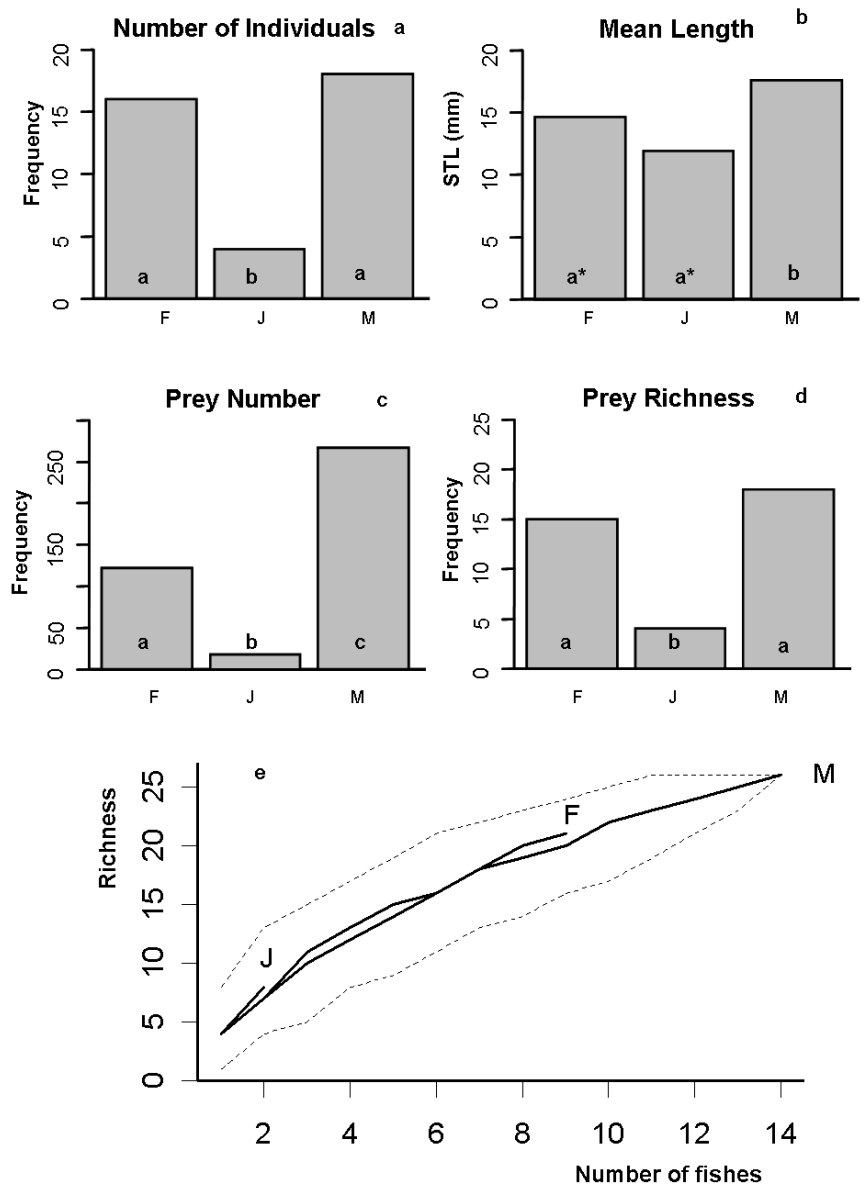

Fig. 5. Sampled fishes of C. melanotaenia and differences between demographic groups (F, J and $\mathrm{M}$ ) in: (a) number of collected individuals, (b) body sizes measured as STL, (c) total number of prey recorded at gut analysis, and (d) prey richness at the taxonomic level detailed in Table 1. (e) Rarefaction curves for each class. Dashed lines indicate the confident interval at $95 \%$.

difference is associated with the consumption of mollusk preys. For the rest of the species, despite the differences, there seems to be no important prey association.

\section{Discussion}

In our studied system, annual killifishes represents the most abundant and conspicuous top predators, being an important component of the temporal pond ecosystems. In the light of ephemeral habitat, a top predator might have a generalist diet, including the major available quantity of preys. Congruently, our results indicate that the four studied species could be considered as generalist predators, with differences between species and demographic groups, mostly related to size differences. Although there is scarce information about temporal killifish diets, available evidence suggests that this 


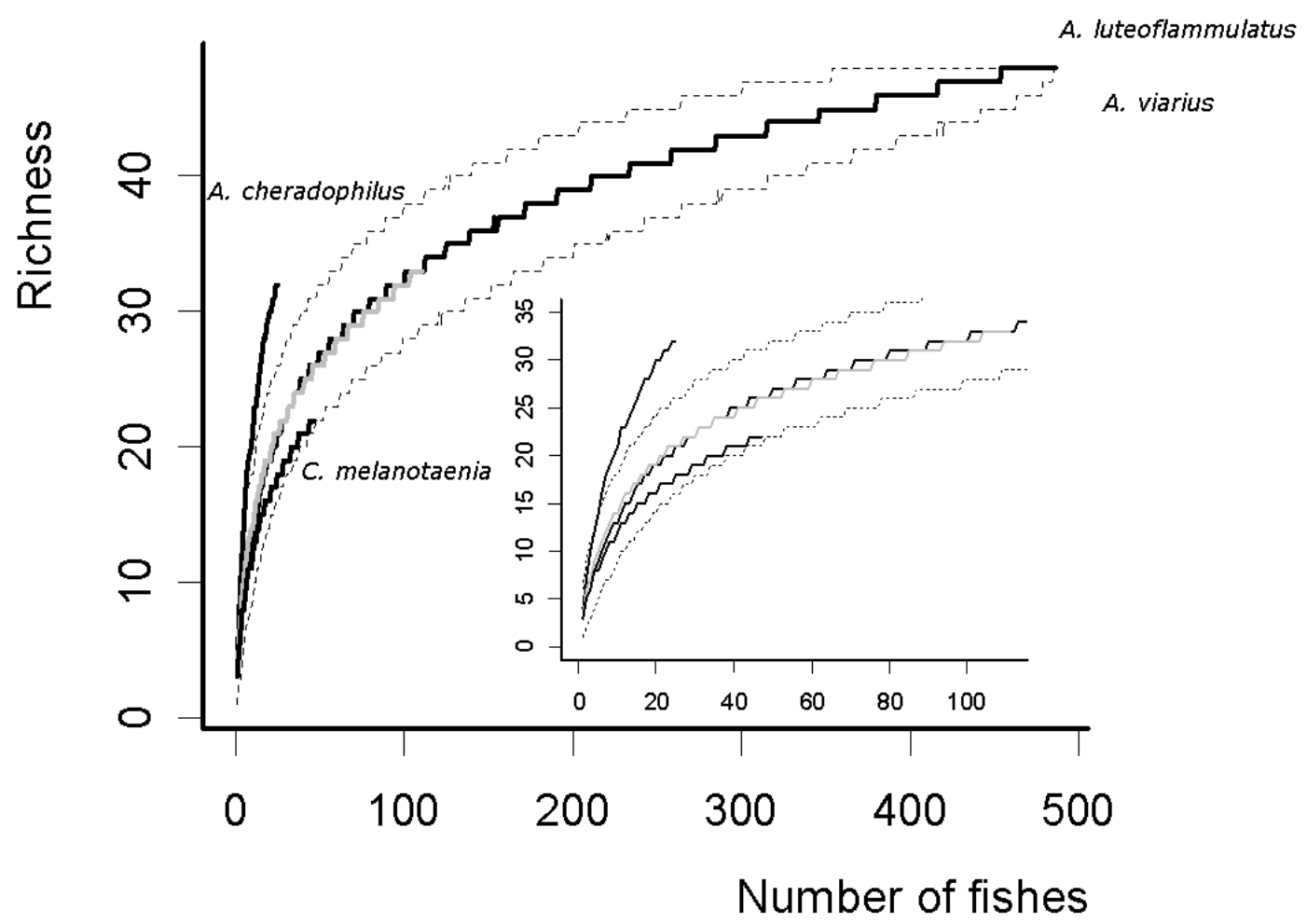

Fig. 6. Rarefaction curves applied for the categorized diet items of Cynopoecilus melanotaenia, Austrolebias luteoflammulatus, A. viarius and A. cheradophilus. Dashed lines indicate the confident interval at $95 \%$.

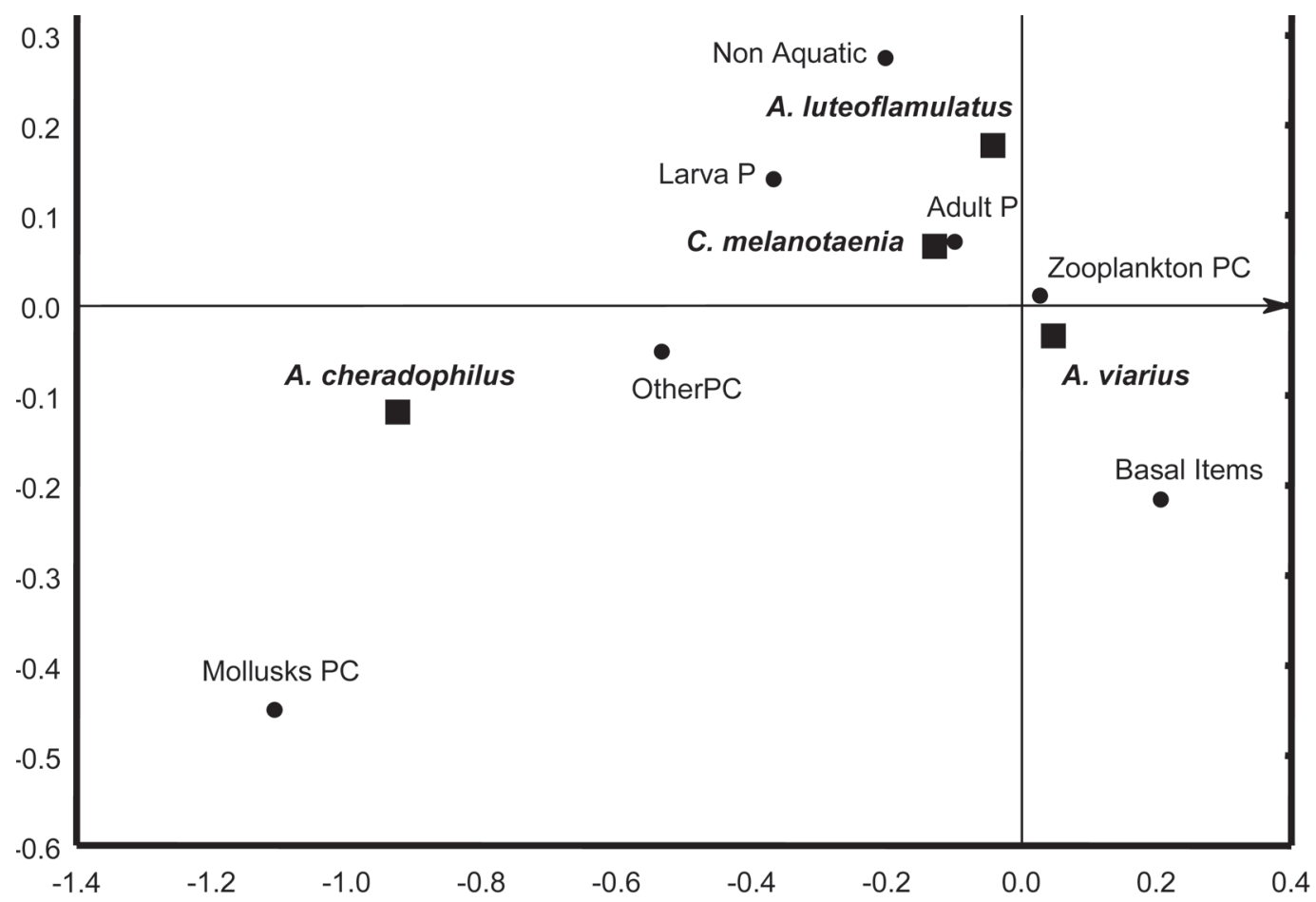

Fig. 7. Correspondence analysis of diet items (\%) and the studied killifish species (\%): Cynopoecilus melanotaenia, Austrolebias luteoflammulatus, A. viarius and A. cheradophilus. The preys were classified in Basal items, Primary Consumers (PC: Zooplankton, Molluscs and Other), Predators (P: Adult and Larva), and Non Aquatic items. 
Table 2. Categorized diet items for A. viarius (Av), A. luteoflamulatus ( $A l)$, C. melanotaenia $(\mathrm{Cm})$ and A. cheradophylus $(A c)$. The preys were classified in Basal items, Primary Consumers (PC: Zooplankton, Molluscs and Other), Predators (P: Adult and Larva), and Non Aquatic items. For each item it is provided the result of G-test $(\mathrm{G})$, the freedom degree (df) and the probability $(\mathrm{P})$, for differences in frequency.

\begin{tabular}{lcccccccc}
\hline & $A v$ & $A l$ & $C m$ & $A c$ & $\mathrm{G}$ & df & $\mathrm{P}$ \\
\hline Adult Predator & 113 & 28 & 4 & 6 & 263.8 & 3 & $<0.0001$ \\
Larva Predator & 144 & 45 & 15 & 16 & 425.3 & 3 & $<0.0001$ \\
Non Aquatic preys & 133 & 54 & 3 & 10 & 428.0 & 3 & $<0.0001$ \\
Molluscs Primary Consumers & 60 & 4 & 5 & 18 & 32.7 & 3 & $<0.0001$ \\
Zooplankton Primary Consumers & 8428 & 1586 & 435 & 215 & 111033.6 & 3 & $<0.0001$ \\
Other Primary Consumers & 264 & 59 & 22 & 41 & 1248.7 & 3 & $<0.0001$ \\
Basal Items & 689 & 54 & 11 & 3 & 4363.2 & 3 & $<0.0001$ \\
\hline
\end{tabular}

probably represents a common attribute of the group biology (e.g. Simpsonichthys constanciae and Leptolebias cruzi at Rio das Ostras, Brazil, Costa, 1995).

Observed differences in diet richness among killifish species and demographic groups could be related to variations in body sizes (McLaughlin, 1989; Woodward et al., 2005). Among the studied species, larger killifishes presented more diverse diets (Fig. 6). Within species, males typically presented a more diverse diet than females, and juveniles a poorer diet than adults (Figs. 2e-3e-4e-5e). Evidence suggests that as predator body size increases, larger prey items are progressively added to diet (e.g. insect larvae), faster than smaller species (e.g. zooplankton) are eliminated (Woodward $\&$ Hildrew, 2002). As a result, a larger predator eats virtually all the prey species consumed by smaller predators, adding bigger items available at the system (Woodward \& Hildrew, 2002). Observed patterns in all the species herein studied are congruent with an increase in diet richness with body size.

Size dimorphism between sexes has been suggested as a main determinant of diet variation (Shine, 1989; Pearson et al., 2002). Concordant with previous reports, males of Austrolebias and Cynopoecilus are larger than females (Vaz Ferreira et al., 1964; Costa, 1995; Arenzon et al., 2001). Further, sexual differences in diet are suggested to be favored by natural selection, when morphology or behavior constrains each species to a limited range of resource (Colwell, 2000). The lack of significant differences between the size of the different sexes in $A$. cheradophilus could be related with the reduced statistical power from the low number of individuals collected.

In the studied system, the most common species was $A$. viarius, followed by A. luteoflammulatus comprising both species $89.4 \%$ of the observed individuals (Table 1 ). These species were mainly represented by juvenile individuals (Figs. 2a-3a), while less abundant species-A. cheradophilus and C. melanotaenia - presented greater incidences of adult individuals (Figs. 4a- 5a). These different patterns could originate from asynchrony in hatching times and/or by interspecific differences in growth rates. Samples were taken at the initial phase of pond life, suggesting that temporal separation in life cycles among species is probably occurring.
This suggest that the largest-A. cheradophilus - and the smallest - C. melanotaenia - killifish species appeared early in the hydrological period while the middle size species develop later. Inter-specific differences in developing times have not been previously evaluated in annual killifishes. Its consequences could be the strong constraining of developing time, being actually less than the short pond life. This fact reinforces temporal limitations, and so, this cost should surpass costs related to competition or predation (Houston and McNamara, 1999). These strategies could maintain killifishes diversity, despite of the occurrence of four generalist vertebrate predators in a small, time constrained ecosystem (Wilbur, 1987).

Temporal systems are generally identified as a refuge for fish where species sensitive to predation reproduce. The annual killifishes are giving a singular community structure, coexisting with anuran larvae (Hypsiboas pulchellus, Odontophrynus americanus, Scinax squalirostris and $S$. granulatus, unpublished data). The absences of tadpoles in fish gut content, suggests that predation is not a main determinant of this taxa coexistence, as is the case in other communities (Kats et al., 1988; Alford, 1999). The existence of anti-predation defenses has identified elsewhere as a frequent mechanism of predation avoidance by amphibians (Alford, 1999; Ruxton et al., 2004). However, the large size of the observed tadpoles, always larger than killifishes, indicate that size refuge to predation could be the most important anti predation mechanism in this system (Chase, 1999).

The present article represents the first report of the trophic ecology of four annual killifishes that coexist at the same wetland system. The study attempts to advance in the understanding the natural history of these species and their ecological communities, as a basic tool for conservation and future life history studies. The three Austrolebias species are endemic to this region, only having $C$. melanotaenia a wider distribution (D'Anatro \& Loureiro, 2005; Costa, 2006). Although being located in a MAB reserve, the system is located in private farms, and future land management practices, can affect the ponds and their dynamics. Further studies concerning species and their communities are necessary in order to conserve this species and their ecosystem. 


\section{Acknowledgements}

This study was funded by Fondo Clemente Estable grant 05-076 to M. A., G. L. and S. C. and by FONDECYTFONDAP grant 1501-0001 (Programs 2) to M.A. Authors thanks the help during field work to Tito Olivera, Octavio, Mauro Berazategui \& Andrés Canavero, and to field owners of Barra Grande and El Gurí Ranchs that allowed us to work in their lands.

\section{Literature Cited}

Alford, R. A. 1999. Ecology: resource use, competition, and predation. Pp. 240-278. In: McDiarmid, R. W. \& R. Altig (Eds.). Tadpoles: The Biology of Anuran Larvae. Chicago, University of Chicago Press, 444p.

Arenzon, A., A. C. Peret \& M. B. C. Bohrer. 2001 Growth of the annual fish Cynopoecilus melanotaenia (Regan, 1912) based in a temporary water body population in Rio Grande Do Sul State, Brazil (Cyprinodontiformes, Rivulidae). Revista Brasileira de Biologia, 61(1): 117-123.

Arezzo, M. J., L. Pereiro \& N. Berois. 2005. Early development in the annual fish Cynolebias viarius. Journal of Fish Biology, 66(5): 1357-1370.

Arim, M. \& O. Barbosa. 2002. Humped pattern of diversity: fact or artifact? Science, 297:1763.

Arim, M. \& F. M. Jaksic. 2005. Productivity and food web structure: association between productivity and link richness among top predators. Journal of Animal Ecology, 74: 31-40.

Arim, M., P. A. Marquet \& F. M. Jaksic. 2007. On the relationship between productivity and food chain length at different ecological levels. American Naturalist, 169: 62-72.

Berryman, A. A. 1999. Principles of population dynamics and their application. Cheltenham, Stanley Thornes, 243p.

Brown, J. H., J. F. Gillooly, A. P. Allen, V. M. Savage \& G. B. West. 2004. Toward a metabolic theory of ecology. Ecology, 85: 1771-1789.

Burgis, M. J. \& P. Morris. 1987. The natural history of lakes. Cambridge Cambridge University Press, 218p.

Chase, J. M. 1999. Food web effects of prey size-refugia: variable interactions and alternative stable equilibria. American Naturalist, 154: 559-570.

Colwell, R. K. 2000. Rensch's rule crosses the line: convergent allometry of sexual size dimorphism in hummingbirds and flower mites. American Naturalist, 156: 495-510.

Consoli, R. A. G. B. \& R. L. de Olivera. 1994. Principais mosquitos de importancia sanitaria no Brasil. Rio de Janeiro, Fiocruz. 225p.

Costa, C., S. Ide \& C. E. Simonka. 2006. Insetos imaturos. Metamorfose e identificação. Ribeirão Preto, Holos Editora, 249p.

Costa, W. J. E. M. 1995a. Pearl Killifishes: The Cynolebiatinae: systematics and biogeography of the Neotropical annual fish subfamily (Cyprinodontiformes: Rivulidae). Neptune City, TFH Publications, 128p.

Costa, W. J. E. M. 1995b. Revision of the Neotropical Annual Fish Genus Cynopoecilus (Cyprinodontiformes: Rivulidae). Copeia, 1995(2): 456-465.

Costa, W. J. E. M. 2006. The South American annual killifish genus Austrolebias (Teleostei: Cyprinodontiformes: Rivulidae): phylogenetic relationships, descriptive morphology and taxonomic revision. Zootaxa, 1213: 1-162.

D'Anatro, A. \& M. Loureiro. 2005. Geographic variation in Austrolebias luteoflamulatus Vaz Ferreira, Sierra \& Scaglia(Cyprinodontiformes, Rivulidae). Journal of Fish Biology, 67(3): 849-865.

Errea, A. \& E. Danulat. 2001. Growth of the annual fish, Cynolebias viarius (Cyrinodontiformes), in the natural habitat compared to laboratory conditions. Environmental Biology of Fishes. 61:261-268.

Houston, A. I. \& J. M. McNamara. 1999. Models of adaptive behaviour: an approach based on state. Cambridge, Cambridge University Press, 378p.

Hughes, R. N. 1993. Introduction. Pp. 1-9. In: Hughes, R. N. (Ed.). Diet selection, an interdisciplinary approach to foraging behaviour. Oxford, Blackwell Scientific Publications, 221p.

Kats, L. B., J. W. Petranka \& A. Sih. 1988. Antipredator defenses and the persistence of amphibian larvae with fishes. Ecology, 69(6): 1865-1870.

Gotelli, N. J. \& R. K. Colwell. 2001. Quantifying biodiversity: procedures and pitfalls in the measurement and comparison of species richness. Ecology Letters, 4: 379-391.

Gotelli, N. J. \& G. R. Graves. 1996. Null models in ecology. Washington DC, Smithsonian Institution Press, 368p.

Greenacre, M. J. 1984. Theory and applications of correspondence analysis. London, London Academic Press, 223p.

Ludwig, D. \& L. Rowe. 1990. Life history strategies for energy gain and predator avoidance under time constraints. American Naturalist, 135: 686-707.

McLaughlin, R. L. 1989. Search modes of birds and lizards: evidence for alternative movement patterns. American Naturalist, 133: 654-670.

McNAB, B. K. 2002. The physiological ecology of vertebrates. Ithaca, Cornell University Press, 576p.

Manly, B. F. J. 1997. Randomization, bootstrap and Monte Carlo methods in biology. New York, Chapman \& Hall, 399p.

Magurran, A. E. 1988. Ecological diversity and its measurement. Princeton, Princeton University, 192p.

Marcus, V. \& S.C. Weeks. 1997. The effects of pond duration on the life history of an ephemeral pond crustacean, Eulimnadia texana. Hydrobiologia, 359: 213-221.

Motta, R. L. \& V. S. Uieda. 2004. Diet and trophic groups of an aquatic insect community in a tropical stream. Revista Brasileira de Biologia, 64: 809-817.

Mura, G., G. Fancello \& S. Di Giuseppe. 2003. Adaptive strategies in populations of Chirocephalus diaphanus (Crustacea, Anostraca) from temporary waters in the Reatine Apennines (Central Italy). Journal of Limnology, 62(1): 35-40.

Naya, D. E., M. Arim \& R. Vargas. 2002. Diet of South American fur seals (Arctocephalus australis) in Isla de Lobos, Uruguay. Marine Mammal Science, 18: 734-745.

Nelson, J. S. 2006. Fishes of the world. 4th Edition. New York, John Wiley and Sons, 601p.

Pearson, D., R. Shine \& R. How. 2002. Sex-specific niche partitioning and sexual size dimorphism in Australian pythons (Morelia spilota imbricata). Biological Journal of the Linnean Society, 77(1): 113-125.

Peña, L. E. 2001. Introducción al estudio de los insectos de Chile. Santiago Editorial Universitaria, 256p.

Peltzer, P. M. \& R. C. Lajmanovich. 2004. Anuran tadpole assemblages in riparian areas of the Middle Parana River, Argentina. Biodiversity and Conservation 13: 1833-1842.

Relyea, R. A. \& E. E. Werner. 2000. Morphological plasticity in four larval anurans distributed along an environmental gradient. Copeia, 2000: 178-190.

Rosenzweig, M. L. 1999. Species diversity. Pp. 249-281. In: J. 
McGlade (Ed.). Advanced ecological theory principles and applications. Oxford, Blackwell Science, 354p.

Ruxton, G. D., T. N. Sherratt \& M. P. Speed. 2004. Avoiding attack: the evolutionary ecology of crypsis, warning signals and mimicry. Oxford, Oxford University Press, 249p.

Scheel, J. J. 1962. Factors governing development of killie eggs. Tropicals, 7(2): 9-15.

Shine, R. 1989. Ecological Causes for the Evolution of Sexual Dimorphism: A Review of the Evidence. The Quarterly Review of Biology, 64(4): 419-461.

Skelly, D.K. 1995. A Behavioral Trade-Off and Its Consequences for the Distribution of Pseudacris Treefrog Larvae. Ecology, 76(1): 150-164.

Sokal, R. R. \& F. J. Rohlf. 1995. Biometry. 3rd edition. New York, W.H. Freeman and Co, 887p.

Thébault, E. \& M. Loreau. 2006. The relationship between biodiversity and ecosystem functioning in food webs. Ecological Research, 21: 17-25.

Thorp, J. H. \& A. P. Covich. 2001. Ecology and classification of North American freshwater invertebrates. $2^{\text {nd }}$ edition. San Diego, Academic Press, 1056p.

Vaz-Ferreira, R., B. Sierra de Soriano \& S. Scaglia de Paulete. 1964. Tres especies nuevas del Genera Cynolebias Steindachner 1876 (Teleostomi, Cyprinodontidae). Comunicaciones Zoológicas del Museo de Historia Natural Montevideo, 8: 1-36.

Ward, A. J. W., P. J. B. Hart \& J. Krauseb. 2004. The effects of habitat- and diet-based cues on association preferences in threespined sticklebacks. Behavioral Ecology, 15(6): 925-929.

Wilbur, H. M. 1987. Regulation of structure in complex systems: experimental temporary pond communities. Ecology, 68(5): 1437-1452.

Winemiller, K. O. 1991. Ecomorphological diversification of freshwater fish assemblages from five biotic regions. Ecological Monographs, 61: 343-365.

Woodward, G., B. Ebenman, M. Emmerson, J. M. Montoya, J. M. Olesen, A. Valido \& P. H. Warren. 2005. Body size in ecological networks. Trends in Ecology and Evolution, 20: 402-409.

Woodward, G. \& A. G. Hildrew. 2002. Body size determinants of niche overlap and intraguild predation within a complex food web. Journal of Animal Ecology, 71: 1063-1074.

Wourms, J. P. 1972. The developmental biology of the annual fishes. pre-embryonic and embryonic diapause of variable duration in the eggs of annual fishes. Journal of Experimental Zoology, 182: 169-200.

Accepted January 2009

Published March 31, 2009 